\title{
Genetic polymorphisms in the glutamate-rich protein of Plasmodium falciparum field isolates from a malaria-endemic area of Brazil
}

\author{
Lilian Rose Pratt-Riccio ${ }^{1 /+}$, Daiana de Souza Perce-da-Silva ${ }^{2}$, \\ Josué da Costa Lima-Junior ${ }^{3}$, Michael Theisen ${ }^{4}$, Fátima Santos ${ }^{5}$, \\ Cláudio Tadeu Daniel-Ribeiro', Joseli de Oliveira-Ferreira ${ }^{3}$, Dalma Maria Banic ${ }^{2}$ \\ 'Laboratório de Pesquisas em Malária ${ }^{2}$ Laboratório de Simulídeos e Oncocercose ${ }^{3}$ Laboratório de Imunoparasitologia, \\ Instituto Oswaldo Cruz-Fiocruz, Rio de Janeiro, RJ, Brasil ${ }^{4}$ Statens Seruminstitut, Copenhagen, Denmark \\ ${ }^{5}$ Laboratório de Entomologia, Laboratório Central Porto Velho, Porto Velho, RO, Brasil
}

The genetic diversity displayed by Plasmodium falciparum, the most deadly Plasmodium species, is a significant obstacle for effective malaria vaccine development. In this study, we identified genetic polymorphisms in P. falciparum glutamate-rich protein (GLURP), which is currently being tested in clinical trials as a malaria vaccine candidate, from isolates found circulating in the Brazilian Amazon at variable transmission levels. The study was performed using samples collected in 1993 and 2008 from rural villages situated near Porto Velho, in the state of Rondonia. DNA was extracted from 126 P. falciparum-positive thick blood smears using the phenol-chloroform method and subjected to a nested polymerase chain reaction protocol with specific primers against two immunodominant regions of GLURP, R0 and R2. Only one R0 fragment and four variants of the $R 2$ fragment were detected. No differences were observed between the two time points with regard to the frequencies of the fragment variants. Mixed infections were uncommon. Our results demonstrate conservation of GLURP-R0 and limited polymorphic variation of GLURP-R2 in P. falciparum isolates from individuals living in Porto Velho. This is an important finding, as genetic polymorphisms in B and T-cell epitopes could have implications for the immunological properties of the antigen.

Key words: Plasmodium falciparum - GLURP - polymorphism

In low-income countries, less than $20 \%$ of residents live to the age of 70 and more than a third of all deaths occur in children under 15. These individuals predominantly die from infectious diseases, with malaria as a top 10 cause of death worldwide (WHO 2011a). Malaria is endemic to 99 countries and, according to the WHO, there were approximately 216 million cases of malaria and an estimated 655,000 deaths due to this disease in 2010. Most malarial deaths occur in children living in Africa, where every minute a child dies from the disease. Six countries (Nigeria, Democratic Republic of the Congo, Burkina Faso, Mozambique, Cote d'Ivoire and Mali) account for $60 \%$, or 390,000 , of malarial deaths annually (WHO 2011b).

In Brazil, malaria is hypo to mesoendemic. It is present throughout the year with clear seasonal fluctuations and is frequently associated with the migratory movements of non-immune individuals to areas where malaria is endemic (Oliveira-Ferreira et al. 2010). Malaria remains a major public health concern in Brazil, where approximately 263,000 cases were registered in $2011,99.8 \%$ of which were in the Amazon Region (SVS/MS 2012).

doi: 10.1590/0074-0276108042013022

Financial support: FIOCRUZ, FAPERJ, CNPq

+ Corresponding author: riccio@ioc.fiocruz.br

Received 2 October 2012

Accepted 26 November 2012
Among the more than 100 parasites in the genus Plasmodium, only five species affect humans (Plasmodium falciparum, Plasmodium vivax, Plasmodium ovale, Plasmodium malariae and Plasmodium knowlesi). Disease due to $P$. falciparum, the most deadly species, is responsible for approximately $90 \%$ of malaria cases worldwide and approximately $15 \%$ of malaria cases in Brazil (WHO 2011b). Taking into account the fact that $P$. falciparum is a major cause of human morbidity and mortality and because of the increased resistance of $P$. falciparum to antimalarial drugs, efforts have been undertaken to combat this particular parasite through the development of malaria vaccines. However, the effectiveness of a vaccine can potentially be compromised by the genetic diversity of the target antigen.

The P. falciparum glutamate-rich protein (GLURP) is a vaccine candidate that has been evaluated in Phase I trials (WHO 2011c). GLURP is expressed during both the pre-erythrocytic and erythrocytic stages of the parasite life-cycle, including on the surface of newly released merozoites (Borre et al. 1991). Immunoepidemiological studies performed in both high and low malaria transmission areas have revealed a high prevalence of GLURP antibodies in adults (Dziegiel et al. 1991, 1993, Boudin et al. 1993, Pratt-Riccio et al. 2005), as well as a significant association between high GLURP-specific antibody levels, low parasite densities (Hogh et al. 1992, 1993) and protection against clinical malaria (Dziegiel et al. 1993, Dodoo et al. 2000, Oeuvray et al. 2000, Soe et al. 2004). Additionally, a recent study of controlled experimental $P$. falciparum infections demonstrated that non-immune in- 
dividuals acquire GLURP antibodies following a single, brief low-density P. falciparum infection (Turner et al. 2011). Moreover, it was recently shown that the antibodies produced in response to GLURP in naturally exposed individuals can inhibit the in vitro growth of $P$. falciparum with or without cooperation from monocytes, suggesting that GLURP could play an important role in controlling parasitaemia (Pratt-Riccio et al. 2011).

GLURP contains an N-terminal non-repeat region (R0), a central repeat region (R1) and an immunodominant C-terminal repeat region (R2). GLURP is highly antigenic and there are few polymorphisms in the gene encoding GLURP in P. falciparum isolates from different geographic regions (Theisen et al. 1995, Stricker et al. 2000). GLURP polymorphisms mainly involve variations in the numbers of repeats of certain genomic sequences that therefore affect the size of the gene and its protein product. Given that a single variant of the gene is found during the blood stages of the parasite, the presence of more than one allele represents a multiclonal infection.

Reports on the genetic variation of $P$. falciparum have demonstrated that the differences in the number of alleles for each gene positively correlate with the degree of endemicity of the area. Previous studies of GLURP in low malaria endemicity areas have reported two alleles in Honduras (Haddad et al. 1999), three alleles in French Guyana (Ariey et al. 1999) and four alleles in Colombia (Montoya et al. 2003). In the high endemicity areas of Africa and Asia, anywhere from eight GLURP alleles in India to 20 alleles in Sudan have been reported (Snounou et al. 1999, Ranjit et al. 2005, A-Elbasit et al. 2007, Mlambo et al. 2007, Mwingira et al. 2011).

Because malarial parasites present in Brazil may have different genetic characteristics compared with parasites in other endemic countries, understanding the genetic variability of the $P$. falciparum variants that are circulating at variable levels of transmission in the Brazilian Amazon Region is critical for the development of vaccination strategies.

The study described here was performed using samples from rural villages situated near Porto Velho, the capital of the state of Rondônia (RO), and a malaria endemic region in the Brazilian Amazon (63.54'13"W $\left.8^{\circ} 45^{\prime} 43^{\prime \prime} \mathrm{S}\right)$. The population of Porto Velho sampled in this study is composed of natives and migrants from several non-endemic areas of Brazil that have lived in the region for 10 years or more. All individuals presented malarial symptoms at the time of blood sampling and were positive for P. falciparum in thick blood smears. Blood samples were collected at two time points: the first sample set was collected in 1993 (time point-1, n $=77$ ) and the second set was collected 15 years later in 2008 (time point-2, $\mathrm{n}=49$ ). The average annual parasite incidence (API) in these villages was 549 in 1993 and 85 in 2008. As a reference, the Brazilian Ministry of Health considers areas with API $\geq 50$ to be high-risk areas.

Written informed consent was obtained from all donors and venous blood samples were taken from $126 P$. falciparum-infected individuals. All P. falciparum malaria patients who were enrolled in this study met the following criteria: (i) they presented symptoms, (ii) their thick blood smears contained only P. falciparum, (iii) they did not use chemoprophylaxis and had not taken anti-malarial drugs (self-treatment), (iv) they were over 12 years old, (v) if female, they were neither pregnant nor breastfeeding and (vi) their blood was collected on the day of diagnosis before initiation of malaria treatment. On average, the patients sought healthcare at Brazilian health services $3.6 \pm 1.8$ days after the onset of their symptoms. After the collection of the blood samples, the patients were immediately treated according to Brazilian Ministry of Health standards for malaria therapy. The study was reviewed and approved by the Oswaldo Cruz Foundation Ethical Committee (258/04).

The fresh blood samples were washed three times with $0.15 \mathrm{M}$ phosphate-buffered saline and the pellets containing packed red blood cells were mixed with equal volumes of cryopreservation solution $(0.9 \% \mathrm{NaCl} / 4.2 \%$ sorbitol $/ 20 \%$ glycerol) and stored in liquid nitrogen until use.

The isolation of DNA from blood was carried out using the phenol/chloroform method previously described (Wilson et al. 1993). The N-terminal non-repeat R0 and the $\mathrm{C}$-terminal repeat $\mathrm{R} 2$ regions of the gene encoding GLURP were amplified using a nested polymerase chain reaction (PCR) method. To amplify the gene segment encoding the R0 region, $2 \mu \mathrm{L}$ of DNA were added to a $50-\mu \mathrm{L}$ reaction containing $3 \mathrm{mM} \mathrm{MgCl}, 15 \mathrm{nmol}$ of each deoxynucleotide triphosphate (dNTP) (Promega, Madison, WI), 100 pmoles of each primer (Invitrogen, USA), $5 \mathrm{U}$ of AmpliTaq $^{\circledR}$ DNA Polymerase (Applied Biosystems, Foster City, CA) and $5 \mu \mathrm{L}$ of $10 \mathrm{X}$ buffer (Promega, Madison, WI). Both single and nested PCR reactions were carried out using the GeneAmp ${ }^{\circledR}$ PCR System 9700 (Applied Biosystem, Foster City, CA) for 35 cycles $\left(1 \mathrm{~min}\right.$ at $94^{\circ} \mathrm{C}, 1$ min at $48^{\circ} \mathrm{C}, 2 \mathrm{~min}$ at $72^{\circ} \mathrm{C}$ ). To amplify the gene segment encoding the $\mathrm{R} 2$ region, $2 \mu \mathrm{L}$ of DNA were added to a $50-\mu \mathrm{L}$ reaction containing $2 \mathrm{mM} \mathrm{MgCl}, 10 \mathrm{nmol}$ of each dNTP (Promega, Madison, WI), 100 pmoles of each primer (Invitrogen, USA), 2.5 U of AmpliTaq ${ }^{\circledR}$ DNA Polymerase (Applied Biosystems, Foster City, CA) and 5 $\mu \mathrm{L}$ of 10X buffer (2.0 mM, Promega, Madison, WI). Both single and nested PCR reactions were performed using the GeneAmp ${ }^{\circledR}$ PCR System 9700 (Applied Biosystem, Foster City, CA) for 35 cycles $\left(1 \mathrm{~min}\right.$ at $94^{\circ} \mathrm{C}, 1 \mathrm{~min}$ at $55^{\circ} \mathrm{C}, 2 \mathrm{~min}$ at $\left.72^{\circ} \mathrm{C}\right)$. Ten microlitres of each PCR reaction were loaded onto a $2.5 \%$ agarose gel (Sigma, Missouri, USA) in 1X TAE buffer (0.04 M TRIS-acetate, 1 $\mathrm{mM}$ ethylenediamine tetraacetic acid) in the presence of ethidium bromide $(0.5 \mu \mathrm{g} / \mathrm{mL})$.

The data were stored in the Fox-plus ${ }^{\circledR}$ (Borland International, Inc, Perrysburg, $\mathrm{OH}$ ) data bank software. Statistica (Microsoft, Inc, Redmond, WA) and Epi-Info 6 (Centers for Disease Control and Prevention, Atlanta, GA) statistical software programs were used for data analysis. The chi-square test was used to analyse the differences in allelic frequencies.

The gender composition of the two groups was similar. The patients were predominantly male, as men comprised $75 \%$ and $80 \%$ of the patients in the first and second time points, respectively. The average age of the individuals was similar between time point-1 $(31 \pm 12$ years old) and time point- 2 ( $29 \pm 11$ years old $)$. The mean 
time of residence in the endemic region was $17 \pm 12$ years for time point- 1 and $20 \pm 12$ time point- 2 . The vast majority of subjects, $97 \%$ and $96 \%$ at time point- 1 and time point-2, respectively, claimed to have experienced at least one previous malaria episode. All individuals presented symptoms at the time of blood sampling and all were positive for $P$. falciparum, as assessed by thick blood films. The mean parasitaemia levels at the time of blood collection were 11,065 $\pm 11,306$ and 2,962 $\pm 2,808$ parasites $/ \mu \mathrm{L}$ blood for time point-1 and time point-2, respectively; thus, the mean parasitaemia levels were higher in patient samples from time point-1 than time point-2 $(\mathrm{p}<0.0001)$.

In all of the samples analysed, only one fragment size was detected for the $\mathrm{R} 0$ region $(1,400 \mathrm{bp})$. Four different R2 fragment sizes were detected among the samples: R2a (750 bp), R2b (800 bp), R2c (950 bp) and R2d (1,100 bp) (Figure). For many antigens, including plasmodial antigens, the polymorphisms are present as variations in the number of tandem repeat sequences and are often found in immunodominant regions of the molecule (Smythe et al. 1990). However, point mutations have been described in several antigens with or without repetitive sequences (Bolad \& Berzins 2000). Our results showed that the $\mathrm{R} 0$ region is conserved with respect to the size of the amplified fragment. The conserved nature of the gene segment encoding R0 suggests an important role for the corresponding protein region in the development and/or viability of the parasite. In addition, our results showed limited polymorphic variation for

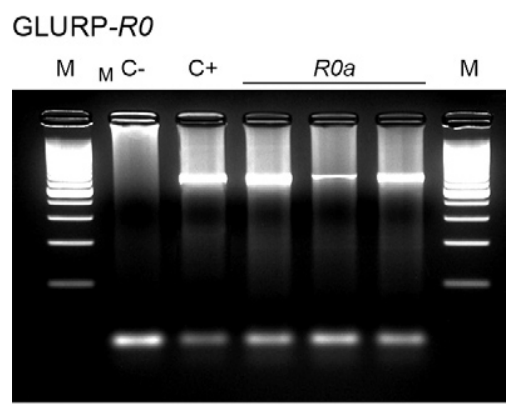

GLURP-R

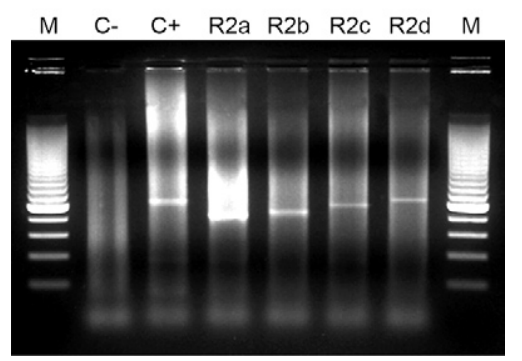

Various glutamate-rich protein (GLURP) fragments amplified by nested polymerase chain reaction from Plasmodium falciparum isolates from Porto Velho, state of Rondônia (RO), Brazil. C-: without DNA; C+: with DNA extracted from a culture of $P$. falciparum (FCR3); M: 200-bp marker; R0a: 1,400 bp; R2a: 750 bp; R2b: 800 bp; R2c: 950 bp; R2d: 1,100 bp. the R2 region of GLURP in P. falciparum isolates from individuals living in a Brazilian malaria endemic area. Similar results were obtained by Stricker et al. (2000), who reported that five GLURP alleles were present in $P$. falciparum isolates circulating in a Brazilian endemic area (Ariquemes, RO). Similarly, studies conducted in low endemicity areas of Honduras, French Guyana and Colombia detected the presence of two, three and five GLURP alleles, respectively (Ariey et al. 1999, Haddad et al. 1999, Montoya et al. 2003, Barrera et al. 2010). Conversely, our observations differ from those made in high endemic areas of Asia and, more strikingly, Africa, where several groups have observed the presence of eight-20 different alleles (Snounou et al. 1999, Ranjit et al. 2005, A-Elbasit et al. 2007, Mlambo et al. 2007, Mwingira et al. 2011). The limited polymorphic variation that we observed in the gene encoding GLURP may reflect the low endemicity of the area we studied. P. falciparum populations from areas of low transmission, such as the Amazon Basin, often display low effective recombination rates and significant linkage disequilibrium. Thus, the $P$. falciparum populations from such areas exhibit low genetic diversity (Anderson et al. 2000, Urdaneta et al. 2001, Machado et al. 2004). An alternative explanation that is not mutually exclusive is that $P$. falciparum most likely originated in Africa (Escalante et al. 1998). Thus, the derivative populations found in Southeast Asia and the Americas may exhibit less genetic diversity as the result of bottlenecks during the colonisation process (Escalante et al. 2002).

One hundred and twenty-eight PCR fragments corresponding to 126 P. falciparum isolates from Porto Velho were obtained by amplifying the $\mathrm{N}$-terminal $\mathrm{R} 2$ region of GLURP. Overall, the frequencies of R2a, R2b, R2c and R2d among the wild P. falciparum isolates were, respectively, $31.2 \%, 29 \%, 11.7 \%$ and $28.1 \%$. The R2c fragment was less prevalent than the R2a, R2b and R2d fragments ( $p=0.0001, R 2 c$ vs. R2a, $p=0.0006$, R2c vs. $\mathrm{R} 2 \mathrm{~b}, \mathrm{p}=0.001$, R2c vs. R2d) (Table). As seen in Table, the isolates collected at time point- 1 contained a lower frequency of the R2c fragment $(7.6 \%)$ compared with the R2a, R2b and R2d fragments ( $<<0.0001$, R2c vs. R2a, p = 0.004, R2c vs. R2b, p $<0.0001$, R2c vs. R2d). At time point-2, we observed that the frequency of the R2c fragment was lower than that of the R2b fragment $(p=0.04)$. There were no differences among the individual frequencies of fragments a-d when comparing the two time points. The R2c allele was detected at low frequency at both time points. The lower frequency of the R2c allele could result from the immunological selection of R2c-containing Plasmodium populations in the infected subjects that we studied (Daubersies et al. 1994) and/or from the influence of host genetic factors, such as human leukocyte antigen (HLA) subtype. A study conducted by Gilbert et al. (1998) reported that the cp26 and cp29 allelic epitopes of the $P$. falciparum CSP variable region were more common in children with HLA-B35, providing evidence that HLA subtypes can influence the distribution of parasite variants. It can also be speculated that random selection differences seen for GLURP-R2 allele distribution among different geographical regions 
could be explained by random shifts in parasite allelic frequencies due to genetic drift in genetically-isolated populations. Thus, allelic frequencies are predicted to change over time. Another hypothesis is that differences in the genetic backgrounds of the studied populations may result in selection of different allelic forms. In this scenario, allelic frequencies are predicted to remain stable over time. Here, we analysed the distribution of GLURP-R2 allelic forms in the samples obtained at the two time points separated by 15 years. Similar allelic frequencies were observed at the two time points, suggesting that the distribution of GLURP-R2 allelic forms is stable over time. This result supports the hypothesis that host genetic background can influence this distribution. Similar results were obtained from two studies conducted in the same area of Brazil that evaluated the distribution of the P126 and EBA-175 allelic forms (Pratt-Riccio et al. 2008, Perce-da-Silva et al. 2011).

It is well recognised that the complexity of infections may vary considerably under different epidemiological scenarios according to the age, gender and immune status of the affected individuals (Bendixen et al. 2001, A-Elbasit et al. 2007). In the present work, no relationship was established between infection patterns and age, gender or time of residence in a particular malaria endemic area.

Considering that multiclonal infection can increase the crossing between gametes of different clones during mosquito transmission to generate novel genotypes by meiotic recombination (Walliker et al. 2005), we evaluated the complexity of $P$. falciparum infection in isolates collected in Porto Velho at the two time points. Single infection (only one R2 fragment) was observed in $98.4 \%$ of the isolates, while mixed infection (more than one R2 fragment) was observed in only $1.6 \%$ of the P. falciparum isolates collected from the studied area. Mixed infection was only observed at time point-1, as one iso-

\section{TABLE}

Distribution of R0 and R2 fragments of glutamate-rich protein of various sizes amplified by nested polymerase chain reaction from Plasmodium falciparum isolates collected in Porto Velho, state of Rondônia, at two time points

\begin{tabular}{cccc}
\hline $\begin{array}{c}\text { Amplified } \\
\text { fragments }\end{array}$ & $\begin{array}{c}\text { Time point-1 } \\
\mathrm{np} / \mathrm{n}(\%)\end{array}$ & $\begin{array}{c}\text { Time point-2 } \\
\mathrm{np} / \mathrm{n}(\%)\end{array}$ & $\begin{array}{c}\text { Fragments } \\
\mathrm{np} / \mathrm{n}(\%)\end{array}$ \\
\hline $\begin{array}{c}\text { R0 region } \\
\text { R0a }\end{array}$ & $77 / 77(100)$ & $49 / 49(100)$ & $126 / 126(100)$ \\
R2 region & & & \\
R2a & $28 / 79(35.4)$ & $12 / 49(24.5)$ & $40 / 128(31.2)$ \\
R2b & $19 / 79(24)$ & $18 / 49(36.7)$ & $37 / 128(29)$ \\
R2c & $6 / 79(7.6)^{a}$ & $9 / 49(18.4)^{b}$ & $15 / 128(11.7)^{c}$ \\
R2d & $26 / 79(33)$ & $10 / 49(20.4)$ & $36 / 128(28.1)$ \\
\hline
\end{tabular}

$a: \mathrm{p}<0.0001, \mathrm{R} 2 \mathrm{c}$ vs. R2a, $\mathrm{p}=0.004, \mathrm{R} 2 \mathrm{c}$ vs. R2b, $\mathrm{p}<0.0001$, $\mathrm{R} 2 \mathrm{c}$ vs. R2d; $b$ : $\mathrm{p}=0.04, \mathrm{R} 2 \mathrm{~b}$ vs. R2c; $c$ : $\mathrm{p}=0.0001, \mathrm{R} 2 \mathrm{c}$ vs. R2a, p $=0.0006, R 2 c$ vs. R2bp, p $=0.001$, R2c vs. R2d; np: number of amplified fragments. late contained the $\mathrm{R} 2 \mathrm{a} / \mathrm{R} 2 \mathrm{~d}$ fragments and another isolate contained the R2a/R2b fragments. A low frequency of mixed infections was observed in Brazilian isolates from the same area in two different studies evaluating the genetic polymorphisms of the P. falciparum P126 and EBA antigens (Pratt-Riccio et al. 2008, Perce-da Silva et al. 2011). The low level of mixed infection may also reflect the low endemicity of the studied area because the frequency of mixed-clone infections has been correlated with the intensity of transmission. Higher levels of transmission increase the proportion of infections with mixed genotypes; thus, outbreeding predominates in hightransmission areas and inbreeding in low-transmission areas (Anderson et al. 2000, Machado et al. 2004).

Our results demonstrate the conservation of the R0 region and the limited genetic polymorphisms in the R2 region of GLURP in P. falciparum isolates from individuals living in RO. Furthermore, our comparative analysis of the GLURP-R2 allelic forms at the two time points showed that the distribution of R2 allelic forms is stable over time. This is an important finding, given that genetic polymorphisms in B and T-cell epitopes could influence the immunological properties of the antigen. Our results suggest that more detailed studies are required before a GLURP-based vaccine can be designed.

\section{ACKNOWLEDGEMENTS}

To all individuals who participated in this study, for the cooperation and generous donation of blood, and to the FNS/ MMS, for providing facilities in the malaria endemic areas.

\section{REFERENCES}

A-Elbasit IE, A-Elgadir TM, Elghazali G, Elbashir MI, Giha HA 2007. Genetic fingerprints of parasites causing severe malaria in a setting of low transmission in Sudan. J Mol Microbiol Biotechnol 13: 89-95.

Anderson TJ, Haubold B, Williams JT, Estrada-Franco JG, Richardson L, Mollinedo R, Bockarie M, Mokili J, Mharakurwa S, French N, Whitworth J, Velez ID, Brockman AH, Nosten F, Ferreira MU, Day KP 2000. Microsatellite markers reveal a spectrum of population structures in the malaria parasite Plasmodium falciparum. Mol Biol Evol 17: 1467-1482.

Ariey F, Chalvet W, Hommel D, Peneau C, Hulin A, MercereauPuijalon O, Duchemin JB, Sarthou JL, Reynes JM, Fandeur T 1999. Plasmodium falciparum parasites in French Guiana: limited genetic diversity and high selfing rate. Am J Trop Med Hyg 61: 978-985.

Barrera SM, Pérez MA, Knudson A, Nicholls RS, Guerra AP 2010. Genotypic survey of Plasmodium falciparum based on the msp1, msp2 and glurp genes by multiplex PCR. Biomedica 30: 530-538.

Bendixen M, Msangeni HA, Pedersen BV, Shayo D, Bodker R 2001. Diversity of Plasmodium falciparum populations and complexity of infections in relation to transmission intensity and host age: a study from the Usambara Mountains, Tanzania. Trans R Soc Trop Med Hyg 95: 143-148.

Bolad A, Berzins K 2000. Antigenic diversity of Plasmodium falciparum and antibody-mediated parasite neutralization. Scand $J$ Immunol 52: 233-239.

Borre MB, Dziegiel M, Hogh B, Petersen E, Rieneck K, Riley E, Meis JF, Aikawa M, Nakamura K, Harada M, Wind A, Jacobsen PH, Cowland J, Jepsen S, Axelsen NH, Vuust J 1991. Primary structure and localization of a conserved immunogenic Plasmodium 
falciparum glutamate rich protein (GLURP) expressed in both the pre-erythrocytic and erythrocytic stages of the vertebrate life cycle. Mol Biochem Parasitol 49: 119-131.

Boudin C, Chumpitazi B, Dziegiel M, Peyron F, Picot S, Hogh B, Ambroise-Thomas P 1993. Possible role of specific immunoglobulin $\mathrm{M}$ antibodies to Plasmodium falciparum antigens in immunoprotection of humans living in a hyperendemic area, Burkina Faso. J Clin Microbiol 31: 636-641.

Daubersies P, Sallenave-Sales S, Trape JF, Raharimalala L, Rogier C, Contamin H, Fandeur T, Daniel-Ribeiro CT, Mercereau-Puijalon O, Druilhe P 1994. PCR characterization of isolates from various endemic areas: diversity and turn over of Plasmodium falciparum populations are correlated with transmission. Mem Inst Oswaldo Cruz 89 (Suppl. II): 9-12.

Dodoo D, Theisen M, Kurtzhals JA, Akanmori BD, Koram KA, Jepsen S, Nkrumah FK, Theander TG, Hviid L 2000. Naturally acquired antibodies to the glutamate-rich protein are associated with protection against Plasmodium falciparum malaria. $J$ Infect Dis 181: 1202-1205.

Dziegiel M, Borre MB, Jepsen S, Hogh B, Petersen E, Vuust J 1991. Recombinant Plasmodium falciparum glutamate rich protein; purification and use in enzyme-linked immunosorbent assay. Am J Trop Med Hyg 44: 306-313.

Dziegiel M, Rowe P, Bennett S, Allen SJ, Olerup O, Gottschau A, Borre M, Riley EM 1993. Immunoglobulin M and G antibody responses to Plasmodium falciparum glutamate-rich protein: correlation with clinical immunity in Gambian children. Infect Immun 61: 103-108.

Escalante AA, Freeland DE, Collins WE, Lal AA 1998. The evolution of primate malaria parasites based on the gene encoding cytochrome b from the linear mitochondrial genome. Proc Natl Acad Sci USA 95: 8124-8129.

Escalante AA, Grebert HM, Isea R, Goldman IF, Basco L, Magris M, Biswas S, Kariuki S, Lal AA 2002. A study of genetic diversity in the gene encoding the circumsposozoite protein (CSP) of Plasmodium falciparum from different transmission areas. XVI. Asembo Bay Cohorto Project. Mol Biochem Parasitol 125: 83-90.

Gilbert SC, Plebanski M, Gupta S, Morris J, Cox M, Aidoo M, Kwiatkowski D, Greenwood BM, Whittle HC, Hill AV 1998. Association of malaria parasite population structure, HLA, and immunological antagonism. Science 279: 1173-1177.

Haddad D, Snounou G, Mattei D, Enamorado IG, Figueroa J, Ståhl S, Berzins K 1999. Limited genetic diversity of Plasmodium falciparum in field isolates from Honduras. Am J Trop Med Hyg 60: 30-34.

Hogh B, Marbiah NT, Petersen E, Dolopaye E, Willcox M, Björkman A, Hanson AP, Gottschau A 1993. Classification of clinical falciparum malaria and its use for the evaluation of chemosuppression in children under six years of age in Liberia, West Africa. Acta Trop 54: 105-115.

Hogh B, Petersen E, Dziegiel M, David K, Hanson A, Borre M, Holm A, Vuust J, Jepsen S 1992. Antibodies to a recombinant glutamate-rich Plasmodium falciparum protein: evidence for protection of individuals living in a holoendemic area of Liberia. $A m J$ Trop Med Hyg 46: 307-313.

Machado RL, Povoa MM, Calvosa VS, Ferreira MU, Rossit AR, dos Santos EJ, Conway DJ 2004. Genetic structure of Plasmodium falciparum populations in the Brazilian Amazon Region. J Infect Dis 190: 1547-1555.

Mlambo G, Sullivan D, Mutambu SL, Soko W, Mbedzi J, Chivenga J, Jaenisch T, Gemperli A, Kumar N 2007. Analysis of genetic polymorphism in select vaccine candidate antigens and microsatellite loci in Plasmodium falciparum from endemic areas at varying altitudes. Acta Trop 102: 201-205.
Montoya L, Maestre A, Carmona J, Lopes D, do Rosario V, Blair S 2003. Plasmodium falciparum: diversity studies of isolates from two Colombian regions with different endemicity. Exp Parasitol 104: 14-19.

Mwingira F, Nkwengulila G, Schoepflin S, Sumari D, Beck HP, Snounou G, Felger I, Olliaro P, Mugittu K 2011. Plasmodium falciparum $\mathrm{msp} 1, \mathrm{msp} 2$ and glurp allele frequency and diversity in sub-Saharan Africa. Malar J 10: 79.

Oeuvray C, Theisen M, Rogier C, Trape JF, Jepsen S, Druilhe P 2000. Cytophilic immunoglobulin responses to Plasmodium falciparum glutamate-rich protein are correlated with protection against clinical malaria in Dielmo, Senegal. Infect Immun 68: 2617-2620.

Oliveira-Ferreira J, Lacerda MV, Brasil P, Ladislau JL, Tauil PL, Daniel-Ribeiro CT 2010. Malaria in Brazil: an overview. Malar J 9: 115 .

Perce-da-Silva DS, Banic DM, Lima-Junior JC, Santos F, DanielRibeiro CT, de Oliveira-Ferreira J, Pratt-Riccio LR 2011. Evaluation of allelic forms of the erythrocyte binding antigen 175 (EBA175) in Plasmodium falciparum field isolates from Brazilian endemic area. Malar J 10: 146.

Pratt-Riccio LR, Bianco-Junior C, Totino PRR, Perce-da-Silva DS, Silva LA, Riccio EKP, Ennes-Vidal V, Neves-Ferreira AGC, Perales J, da Rocha SLG, Dias-da-Silva F, Ferreira-da-Cruz MF, Daniel-Ribeiro CT, de Oliveira-Ferreira J, Theisen M, Carvalho LJM, Banic DM 2011. Antibodies against the Plasmodium falciparum glutamate-rich protein from naturally exposed individuals living in a Brazilian malaria-endemic area can inhibit in vitro parasite growth. Mem Inst Oswaldo Cruz 106 (Suppl. I): 34-43.

Pratt-Riccio LR, Lima-Junior JC, Carvalho LJ, Theisen M, EspíndolaMendes EC, Santos F, Oliveira-Ferreira J, Goldberg AC, DanielRibeiro CT, Banic DM 2005. Antibody response profiles induced by Plasmodium falciparum glutamate-rich protein in naturally exposed individuals from a Brazilian area endemic for malaria. Am J Trop Med Hyg 73: 1096-1103.

Pratt-Riccio LR, Sallenave-Sales S, de Oliveira-Ferreira J, da Silva BT, Guimarães ML, Santos F, de Simone TS, Morgado MG, de Simone SG, Ferreira-da-Cruz MF, Daniel-Ribeiro CT, Zalis MG, Camus D, Banic DM 2008. Evaluation of the genetic polymorphism of Plasmodium falciparum P126 protein (SERA or SERP) and its influence on naturally acquired specific antibody responses in malaria-infected individuals living in the Brazilian Amazon. Malar J 7: 144.

Ranjit MR, Das A, Das BP, Das BN, Dash BP, Chhotray GP 2005. Distribution of Plasmodium falciparum genotypes in clinically mild and severe malaria cases in Orissa, India. Trans $R$ Soc Trop Med Hyg 99: 389-395.

Smythe JA, Peterson MG, Coppel RL, Saul AJ, Kemp DJ, Anders RF 1990. Structural diversity in the 45-kilodalton merozoite surface antigen of Plasmodium falciparum. Mol Biochem Parasitol 39: 227-234.

Snounou G, Zhu X, Siripoon N, Jarra W, Thaithong S, Brown KN, Viriyakosol S 1999. Biased distribution of msp1 and msp2 allelic variants in Plasmodium falciparum populations in Thailand. Trans R Soc Trop Med Hyg 93: 369-374.

Soe S, Theisen M, Roussilhon C, Aye KS, Druilhe P 2004. Association between protection against clinical malaria and antibodies to merozoite surface antigens in an area of hyperendemicity in Myanmar: complementarity between responses to merozoite surface protein 3 and the 220-kilodalton glutamate-rich protein. Infect Immun 72: 247-252.

Stricker K, Vuust J, Jepsen S, Oeuvray C, Theisen M 2000. Conservation and heterogeneity of the glutamate-rich protein (GLURP) 
among field isolates and laboratory lines of Plasmodium falciparum. Mol Biochem Parasitol 111: 123-130.

SVS/MS - Secretaria de Vigilância em Saúde/Ministério de Saúde 2012. Dados epidemiológicos de malária por estado. Amazônia Legal, janeiro a dezembro de 2010 e 2011. Available from: portal.saude. gov.br/portal/arquivos/pdf/boletim_malaria_2010_2011.pdf.

Theisen M, Vuust J, Gottschau A, Jepsen S, Hogh B 1995. Antigenicity and immunogenicity of recombinant glutamate-rich protein of Plasmodium falciparum expressed in Escherichia coli. Clin Diagn Lab Immunol 2: 30-34.

Turner L, Wang CW, Lavstsen T, Mwakalinga SB, Sauerwein RW, Hermsen CC, Theander TG 2011. Antibodies against PfEMP1, RIFIN, MSP3 and GLURP are acquired during controlled Plasmodium falciparum malaria infections in naïve volunteers. PLoS ONE 6: e29025.

Urdaneta L, Lal A, Barnabe C, Oury B, Goldman I, Ayala FJ, Tibayrenc M 2001. Evidence for clonal propagation in natural isolates of Plasmodium falciparum from Venezuela. Proc Natl Acad Sci USA 98: 6725-6729.

Walliker D, Hunt P, Babiker H 2005. Fitness of drug-resistant malaria parasites. Acta Trop 94: 251-259.

WHO - World Health Organization 2011a. The top 10 causes of death. Available from: who.int/mediacentre/factsheets/fs310/en/index. html.

WHO - World Health Organization 2011b. World Malaria Report. Available from: who.int/malaria/world_malaria_report_2011/en/.

WHO - World Health Organization 2011c. Tables of malaria vaccine projects globally. Available from: who.int/vaccine_research/links/ Rainbow/en/.

Wilson CM, Volkman SK, Thaithong S, Martin RK, Kyle DE, Milhous WK, Wirth DF 1993. Amplification of pfmdrl associated with mefloquine and halofantrine in Plasmodium falciparum from Thailand. Mol Biochem Parasitol 57: 151-160. 